"Customer performance and non-financial organizational performance of the Nepalese cellular telecommunications industry"

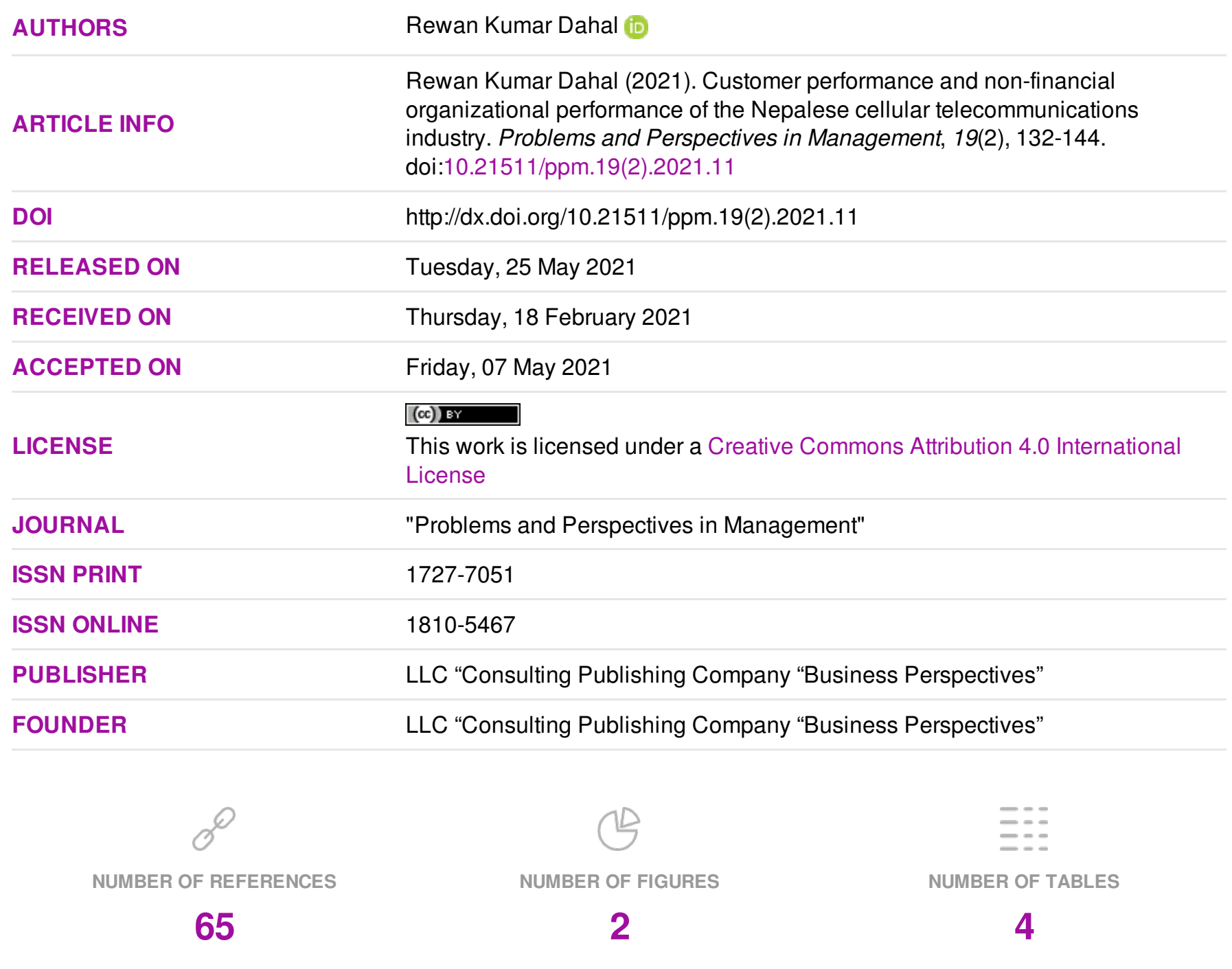

(C) The author(s) 2021. This publication is an open access article. 


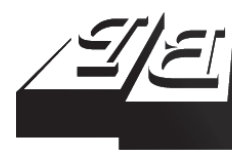

\section{BUSINESS PERSPECTIVES}

O

LLC "CPC "Business Perspectives" Hryhorii Skovoroda lane, 10, Sumy, 40022, Ukraine www.businessperspectives.org
Received on: $18^{\text {th }}$ of February, 2021 Accepted on: $7^{\text {th }}$ of May, 2021 Published on: $25^{\text {th }}$ of May, 2021

๑) Rewan Kumar Dahal, 2021

Rewan Kumar Dahal, Ph.D. Scholar Assistant Professor, Faculty of Management, Nepal Commerce Campus, Tribhuvan University, Kathmandu, Nepal.

\title{
CUSTOMER PERFORMANCE AND NON-FINANCIAL ORGANIZATIONAL PERFORMANCE OF THE NEPALESE CELLULAR TELECOMMUNICATIONS INDUSTRY
}

\begin{abstract}
The study assessed a product or service by customers that met their needs and aspirations. It sought to examine the influence of non-financial customer performance (CP) measures on non-financial organizational performance (NFOP) in the Nepalese cellular telecommunications industry (NCTI). Using a structured questionnaire survey instrument, it employed a descriptive research approach. This study's population included all the global system for mobile (GSM) customers of Nepal Telecom (NT) and Ncell. The sample comprised 385 customers delineated through non-probability sampling techniques. The study's targeted respondents were postgraduate understudies, service holders, business people, and self-employed individuals. The survey instrument was composed of three sections comprising 28 data collection questions. A statistical package for the social sciences (SPSS) and analysis of moment structures (AMOS) programming were used to analyze the collected data. The study applied confirmatory factor analysis (CFA), path analysis (PA), and structural equation modeling (SEM) to evaluate the significance of the hypothesized paths. It was found that $\mathrm{CP}$ had a positive and significant relationship with NFOP in NCTI, with customer retention (CR) being a better predictor, followed by customer loyalty (CL), customer satisfaction (CS), and customer acquisition (CA). This was a cited representative study, not exhaustive, and would help to understand the key drivers of CP in the NCTI.
\end{abstract}

\section{Keywords}

JEL Classification

\section{INTRODUCTION}

Organizational performance (OP) is the activity of an organization to accomplish objectives and destinations, based on a decision taken earlier. Performance is about ability and the future (Lebas, 1995). Performance assessment is the strategy for quantifying the consistency, efficacy, and competitiveness of previous actions (Michaela \& Marketa, 2012). Moullin (2003) defined the term performance appraisal as an assessment of how well organizations perform and the value offered to stakeholders. According to Franco-Santos et al. (2004), performance assessment is a series of processes in which an organization manages the execution of its strategy, communicates its role and success, and affects its stakeholders' behaviors and activities. Organizational success can be handled from many perspectives, one of which is customer performance, which significantly affects customer satisfaction, retention, engagement, and acquisition.

$\mathrm{CP}$ is an assessment by customers of a product or service, whether it meets their requirements and expectations. It was described as an effective response to a product or service's performance compared with 
some standards before or after consumption (Halstead et al., 1994). The performance incorporates many cores or generic and unique metrics such as CL, CR, new CA, customer profitability, targeted market segment, share, etc. (Kaplan \& Norton, 1996). It explains how a business tries to attract, conserve, and deepen targeted customer relationships by differentiating itself from competitors (Atkinson et al., 2014). In this regard, non-financial performance metrics like CS, CR, CL, CA, etc., provide more knowledge and information on OP.

The ultimate challenge for every organization and business pioneer, especially the service industries such as telecommunications services, is satisfying customers in today's hyper-competitive marketplace. Many studies observed that higher CS implies a higher quality of the product and more desire to buy the product (wallet share), and a happier customer positively and significantly influences the business's profitability. It will lead to longer retention if the customers are pleased with the brand. Generally, the cost of becoming a new client is five times the cost to keep up current clients (Reichheld, 1996). A retained customer will demonstrate resilience to competitors' appeal and will be able to provide both requested and unrequested referrals (Omotayo et al., 2008). It is considered that consumers with a longer retention rate are loyal and less likely to turn to alternative providers. To generate brand loyalty for customers, marketers should assist customers with purchasing and build up these new comportments by reminding their value in purchasing and empowering them to purchase these products/services in the future (Rahman et al., 2011).

The literature stated that a financial measure-based performance assessment system is no longer appropriate in the current business environment. It fails to meet consumer needs and is unable to evaluate their reactions. As a result, companies have begun to integrate non-financial metrics into the performance assessment and reporting framework. Gradually, companies are increasingly dependent on non-financial initiatives to ensure future progress. In recent years, both practitioners and analysts have emphasized the need to move beyond financial activities and incorporate a much broader range of non-financial metrics into the organization's performance reporting. Therefore, this study focused on non-financial measures for the NCTI's organizational efficiency as a critical enabler of competitiveness across economies and societies.

Nepal's cellular industry is comparatively new, but development is much quicker than in other sectors. As rivalry among operators has intensified, they need to learn about CP. In this context, the study attempted to answer how non-financial measures influence CP in the NCTI. The study's objective is to examine the power of non-financial interventions for the CP of the NCTI and initiate some discussions to enhance $\mathrm{CP}$.

Non-financial performance metrics have received growing attention from modern companies and businesses to provide additional information and knowledge to managers (Ahmad \& Zabri, 2016a). Practicing non-financial performance metrics in the IT-based service setting is also essential where its daily activity is more complicated than any other type of organization. Therefore, the study analyzed the non-financial CP assessment metrics in the NCTI and established a subjective framework for the Nepalese environment.

\section{LITERATURE REVIEW}

The rising body of literature has widely addressed the increased focus on non-financial performance measures. Amir and Lev (1996) analyzed the value-relevance of non-financial information in wireless communication industries. They found that fi- nancial information alone is essentially irrelevant to the measurement framework of organizational success. The commotion in financial results affected the performance assessment option (Ittner et al., 1997). The more commotion in financial performance, the more prominent the weight of non-financial performance put by the firms. Financial measures are 
usually lagging performance measures, while non-financial measures contribute to efficiency measures that provide insights into potential success (Briggs et al., 2006). Literature showed that CP incredibly influences CS, CR, CL, and CA, resulting in an improved overall OP.

CS metrics lead to customer purchasing behavior, growth in customers, and accounting results (Ittner \& Larcker, 1998b). It is firmly connected to a product or service's reasonable pricing, contributing to CL to the company (Martin-Consuegra et al., 2007). Customer understanding differs broadly by the nature and quality of correspondence, call service, offers, facilities, price, customer care, and service providers' ascribes (Paulrajan \& Rajkumr, 2011). An excellent organization will satisfy or surpass consumer standards while staying economically competitive. It was also suggested that an organization could not survive in today's market environment without offering superior service quality (Lai et al., 2007). Successful business associations recognize their customers' needs and deliver quality services that enhance efficiency (Wang \& Lo, 2002). Associations' response to their customers significantly affects CL and overall OP (Khan, 2010). CP facilitates improved customer service, such as proficiently managing customer grievances, transferring relevant information on time, offering after-sales services, etc. (Joshi et al., 2010), which prompts longer CR with higher CL.

Longer CR with the company affects the more excellent utility a customer produces. The utility reflects the number of factors that the customer spends with the company, including the higher start-up costs to run and retain new customer, raising the value of the transaction, increasing the number of transactions, more profound organizational comprehension, and positive word of mouth promotion (Colgate \& Danaher, 2000). The literature stated that easy payment for telecom services for all customers prompts longer CR and better CP. Customer conveniences, such as recharge, utility bills payments, more friends and families (FNFs), customer care, higher speed internet service, etc., have a significant effect on CR, and organizational commitment is affected by the degree of confidence and part of the long-term relationship in CL (Sanchez \& Iniesta, 2004). Commonsense and valuable correspondence contribute to greater trust and engagement in the relationship (Sharma \& Patterson, 1999). The higher the switching barrier, the more an established carrier is pressured by a customer (Fornell, 2007).

Earlier studies indicate that CL provides a pillar of a company's sustainable competitive advantage. Developing and growing CL is a crucial factor in businesses' growth and success (Kim et al., 2004). Trust and perceived value positively affect CR and CL (Lin \& Wang, 2006). Repurchase intention or re-patronize a preferred product/service consistently in the future is the primary indicator of CL (Oliver, 1997). Zeithaml et al. (1996) have recognized price tolerance as one of the dimensions of CL. When a customer maintains loyalty to a specific enterprise or brand, they will also increase their price tolerance. Loyal customers are priceless, free to positive word of mouth, always give suggestions, and try the company's new products (Lee et al., 2001). Recommending products/services is another standard indicator of a loyal customer. If a customer is pleased, they'll speak to their friends, relatives, and social networks about it.

$\mathrm{CA}$ is the rate of attraction or winning to new customers or businesses or companies and can be measured by the number of new customers or the total sales to new customers (Kaplan \& Norton, 1996). The best way to generate new customers for the next generation of cellular telecommunication services is the value-added features of cellular telecommunications services (such as prepaid top-up recharge offers, E-recharge top-up, a bonus card, mobile warning, SMS, MMS, voice call service, SMS alert, caller tunes, limited-time free internet use, ring tone services, information service, etc.). Customer relationship management understands customers' requirements and behavior, builds long-term relationships, provides sales/service quality, reduces costs (cost efficiency), and improves profitability (Atkinson et al., 2014). The promotion offers reasons to purchase a product or service and plays a significant role in marketing a product in different areas. Unless it catches people's attention, it cannot be effective. With sufficient evidence supporting these arguments, the literature indicates that since many individuals find out about products from others through word of mouth or promotional activities, consumers can become intrigued about purchasing them. Similarly, promotional deals can increase market demand or improve product quality and significantly affect brand choice, purchasing time, and consumers' 
buying quantities. Promotional efforts should also enhance the engagement of customers and promote repeat purchases (Khan, 2012).

The essence of the use and diversity of measurement needs to be addressed in OP measurement systems (Henri, 2006). The OP measurement mechanism could require improvements to be widely used as the final dependent variable (Richard et al., 2009). The disclosure of non-financial information communicates strategic information, resulting in business strategies and management priorities to stakeholders (Omran et al., 2019). Many businesses appear to adjust their performance measurement metrics to track non-financial measures and assess new methods for competitiveness (Ittner et al., 2009; Jacobson \& Mizik, 2009). NFOP disclosure facilitates transparency about the organization's results and efficiency, ultimately improving the overall OP (Kolstad, 2013).

\section{STUDY FRAMEWORK AND HYPOTHESES}

This study is inspired by the theory of stakeholders, which offers a valuable objective for exploring stakeholders' value and new approaches for their assessment. Different stakeholders may vary from what is necessary due to diverse expertise, priori- ties, and contexts. The incorporation of stakeholder evaluations will contribute to the optimization of an organization's existing products and processes. A central concept of much of the literature concerning stakeholder theory is that it helps a firm build value across many different dimensions by concentrating on stakeholders, particularly treating them properly and managing their interests (Bosse et al., 2008). As part of the company's performance, this study focused on collecting, reviewing, assessing, tracking, and communicating customer information and strategies relating to the $\mathrm{CP}$ by taking a single stakeholder category (i.e., customer). The complete structure of the analysis was shown in Figure 1, followed by leading and supporting hypotheses.

Leading hypothesis:

H1: CP positively and significantly affects NFOP.

Supporting hypotheses:

H1a: CP positively and significantly affects CS.

$H 2 b$ : CP positively and significantly affects $C R$.

H3c: CP positively and significantly affects CL.

H4d: CP positively and significantly affects CA.

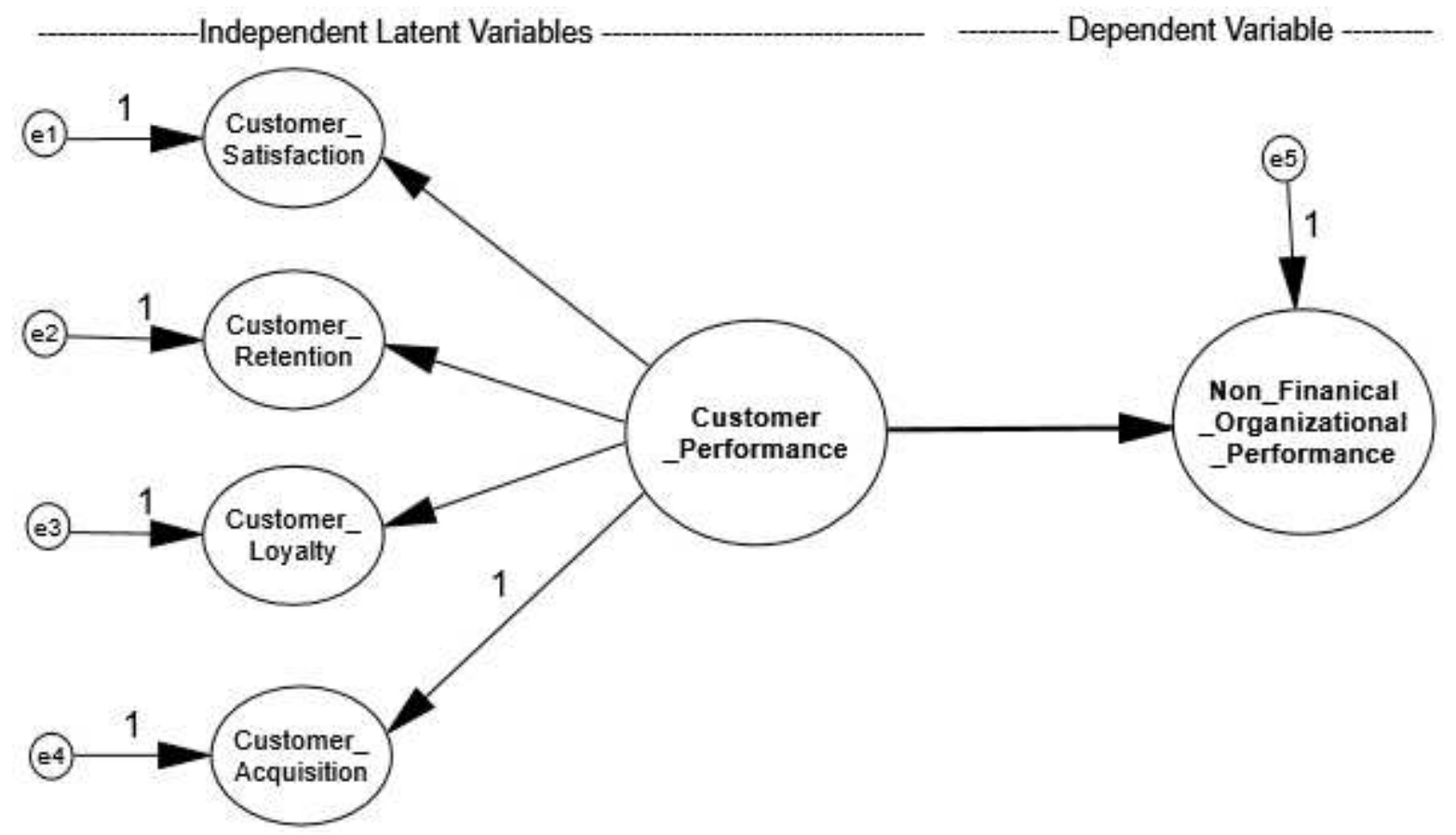

Figure 1. The study structure 


\section{METHODOLOGY}

A standardized questionnaire was developed based on the literature review, which produced quantitative data through a primary survey. SPSS version 23 and AMOS version 21 were used to analyze and interpret the data. The focused population constituted all the GSM customers of NT and Ncell. The examination employed a non-probability sampling method since there was no evidence of active and dead SIM cards issued with the companies. Postgraduate students, service holders, business people, and self-employed individuals were focused as participants. As proposed by Bowerman et al. (2004), the example size was 385 , which was also steady with the general scientific guidance for the example size selection as suggested by Krejcie and Morgan (1970).

The designed survey questionnaire included 28 test questions and was synchronized into three sections. The initial segment looked for general information from the respondents and contained seven inquiries. The subsequent portion mentioned $\mathrm{CP}$ variables in various measurements and contained 17 inquiries. The final section requested the overall non-financial performance variables and included four inquires. The keep going two sections concentrated on the study variables, and a series of close-ended inquiries were composed to obtain the respondents' relevant information. With a 6-point Likert-type scale with $1=$ strongly disagree to $6=$ strongly agree, all survey elements of the examination variables were measured. The 6-point scale was selected because it does not contain the conflicted center score.

The polls were regulated through web and field surveys. Using the database given by the various Nepalese colleges/universities, the web survey was directed among ex-students who were graduated over the most recent five years and work in different parts of Nepal. During the 60 days of September to October 2020, a sum of 500 respondents was approached. The respondents were asked to participate in the survey if they were using either NT or Ncell GSM networks. The web survey received one hundred and twenty-eight responses and reported them in the SPSS. The field survey was then led during the same span of 2020 among the various Nepalese universities' postgraduate understudies and their faculties members. An aggregate of 580 questionnaires was administered, a sum of 283 responses was received. Twenty-six gathered questionnaires were dismissed because of deficient responses, and 257 questionnaires were correctly filled out and used for the study. Therefore, the complete valuable polls were 385 , which were

Table 1. General information on the respondents

\begin{tabular}{|c|c|c|c|c|c|}
\hline \multirow{2}{*}{ Description } & \multicolumn{2}{|c|}{ Respondents in } & \multirow{2}{*}{ Description } & \multicolumn{2}{|c|}{ Respondents in } \\
\hline & Numbers & $\%$ & & Numbers & $\%$ \\
\hline \multicolumn{3}{|c|}{ Company: } & \multicolumn{3}{|c|}{ Respondent's sex: } \\
\hline Nepal Telecom & 193 & 50.1 & Female & 210 & 54.5 \\
\hline Ncell & 192 & 49.9 & Male & 175 & 45.5 \\
\hline \multicolumn{3}{|c|}{ Connection type: } & \multicolumn{3}{|c|}{ Years of experience: } \\
\hline Prepaid & 271 & 70.4 & 6 to 10 Yrs. & 254 & 65.9 \\
\hline Postpaid & 81 & 21.1 & 11 to $15 \mathrm{Yrs}$. & 105 & 27.3 \\
\hline Both & 33 & 8.5 & 16 to 20 Yrs. & 26 & 6.8 \\
\hline \multicolumn{3}{|c|}{ Occupation } & \multicolumn{3}{|c|}{ Geographical spreading: } \\
\hline Students & 181 & 47.0 & Province 1 & 70 & 18.2 \\
\hline Service holders & 160 & 41.6 & Province 2 & 51 & 13.2 \\
\hline Business persons & 24 & 6.2 & Bagmati & 88 & 22.9 \\
\hline Self-employed individuals & 20 & 5.2 & Gandaki & 57 & 14.8 \\
\hline \multicolumn{3}{|l|}{ Age group: } & Lumbini & 58 & 15.1 \\
\hline 25 yrs. and less & 109 & 28.3 & Karnali & 29 & 7.5 \\
\hline 26 to 35 yrs. & 139 & 36.1 & Sudur Pashchim & 32 & 8.3 \\
\hline 36 to 45 yrs. & 73 & 19.0 & Total of each section & 385 & 100.0 \\
\hline 46 to 55 yrs. & 38 & 9.9 & & & \\
\hline 56 yrs. and above & 26 & 6.7 & & & \\
\hline Total of each section & 385 & 100.0 & & & \\
\hline
\end{tabular}


Table 2. Reliability measures

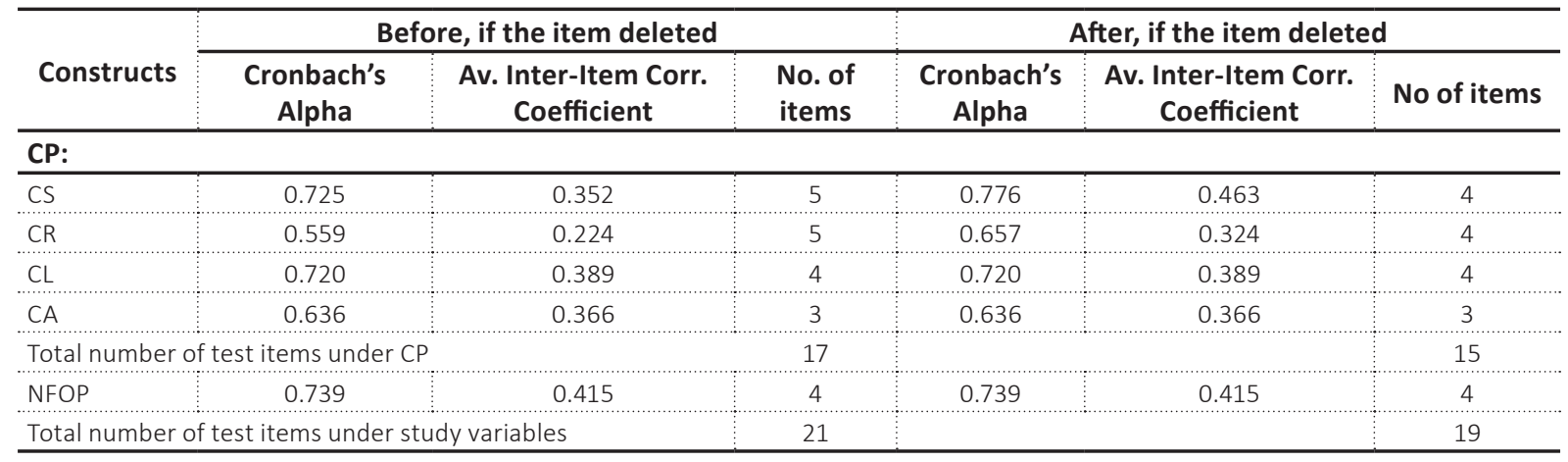

utilized in the study. As per the sample outlined, the general information of the respondents was described in Table 1.

Assorted data at a time and the utilization of self-revealed information may contribute to a common method bias (CMB) and debilitate the connections between the examined variables (Karatepe, 2012). The study evaluated the Harman single-factor test, as suggested by Podsakoff et al. (2003), to determine the CMB's predominance and extent. Cho and Lee (2012) indicated that it would be appropriate to have a CMB if the Harman single-factor does not describe more than $50 \%$ of the variance. The 21 study variables' single-factor contained a variance of $28.395 \%$, well below the threshold value of $50 \%$. Therefore, this analysis was free from the $\mathrm{CMB}$ of the process.

Before evaluating the study model, the analysis employed SPSS (version 23) and AMOS (version 21) programming to assess the constructs' reliability and validity, the reliability measures familiarized in Table 2.

The analysis found that the VAR_8 (price fairness) under the construct CS and the VAR_17 (switching barriers) under the construct CR required de- leting the higher alpha values, if the item deleted. The variables' VAR_8 and VAR_17 also had a low correlation to total correlation. Therefore, the variables' VAR_8 and VAR_17 were not relevant in the NCTI and deleted from the examination. The CS and CL constructs had phenomenal Cronbach's alpha qualities and surpassed the edge value of 0.7 as recommended by Nunnally (1993), while the constructs CR and CA had satisfactory alpha estimates and were greater than the cut-off value of 0.6 as suggested by McKinley et al. (1997). Furthermore, all of the constructs had an impressive average inter-item correlation coefficient and fell within Clark and Watson's (1995) ideal range of 0.15 to 0.50 . Therefore, 15 test variables with four constructs under $\mathrm{CP}$ and four test variables within one construct under NFOP had advanced to further analysis.

The validity of the constructs was tested using convergent and discriminant validity. Table 3 showed the inter-construct correlations and the validity measures of the study model.

As Fornell and Larcker (1981) suggested, the validity measures exhibited that all the constructs had a substantial CoR value. They claimed that if the AVE is under 0.5, however, CoR is above 0.60, the

Table 3. Validity measures

\begin{tabular}{|c|c|c|c|c|c|c|c|c|}
\hline \multirow[t]{2}{*}{ Constructs } & \multirow{2}{*}{$\begin{array}{c}\text { Composite } \\
\text { reliability } \\
\text { (CoR) }\end{array}$} & \multirow{2}{*}{$\begin{array}{c}\text { Average } \\
\text { variance } \\
\text { extracted } \\
\text { (AVE) }\end{array}$} & \multirow{2}{*}{$\begin{array}{l}\text { Maximum } \\
\text { shared } \\
\text { variance } \\
\text { (MSV) }\end{array}$} & \multirow{2}{*}{$\begin{array}{c}\text { Average } \\
\text { shared } \\
\text { variance (ASV) }\end{array}$} & \multicolumn{4}{|c|}{$\begin{array}{l}\text { Square root of AVE (in bold) and Inter- } \\
\text { construct correlation }\end{array}$} \\
\hline & & & & & CS. & CR & $\mathrm{CL}$ & CA \\
\hline CS & 0.80 & 0.50 & 0.50 & 0.31 & 0.71 & & & \\
\hline$C R$ & 0.66 & 0.33 & 0.50 & 0.46 & 0.71 & 0.57 & & \\
\hline $\mathrm{CL}$ & 0.72 & 0.40 & 0.44 & 0.26 & 0.41 & 0.66 & 0.63 & \\
\hline$C A$ & 0.64 & 0.38 & 0.44 & 0.29 & 0.51 & 0.66 & 0.43 & 0.62 \\
\hline
\end{tabular}


latent measures' convergent validity was adequate. The constructs, therefore, dignified the hypothesized-driven facts. On account of discriminant validity, there was a multicollinearity issue since the inter-latent variable correlations overlapped the edge value of 0.7 or higher as suggested by Meyers et al. (2006). Accordingly, as Fornell and Larcker (1981) criteria, AVE ought to be higher than MSV (AVE > MSV), or ASV (AVE > ASV), or the AVE's square root for any specific construct should be higher than the correlations between constructs for suitable discriminant validity. These necessities were not satisfied; therefore, the constructs were not distinct and measured the same concept of CP.

\section{RESULTS AND ANALYSIS}

The study applied CFA, PA, and SEM to assess the noteworthiness of the hypothesized paths and the model's informative power by registering multiple correlation coefficients for each endogenous variable. Figure 2 demonstrated the standardized estimates and the fitness of the underlying model. The model had satisfactory fitness $\left(\chi^{2}=314.032\right.$; $p=0.000 ; \chi^{2} / \mathrm{df}=2.196 ;$ SRMR $=0.073$; RMSEA
$=0.056 ; \mathrm{PCLOSE}=0.123 ; \mathrm{GFI}=0.920 ; \mathrm{AGFI}=$ 0.893; $\mathrm{RFI}=0.836 ; \mathrm{CFI}=0.919 ; \mathrm{NFI}=8.863 ; \mathrm{TLI}=$ 0.903 ) and the measures stood within the expected desired level.

The PA and the study's SEM analyzed the model fit for each tested construct's reliability and validity and performed an overall model. Table 4 shows the key parameter estimates of the model.

As Table 4 shows, all quantifying test variables, error terms, and measuring the relationship between error terms of the model delivered statistically noteworthy critical ratios at $p \leq 0.05$. The test model outcomes yielded standardized regression loads that varied considerably from zero and above the edge level of 0.5 for a good fit (Hair et al., 2006). The Skewness value ( -0.818 to $-0.114)$ and the Kurtosis value $(-0.726$ to +0.262$)$ of the noticed factors have shown normality since data have been recorded in the recommended scope of \pm 2 (George \& Mallery, 2010). Similarly, the absolute value of standardized residual covariance of the factors $(-2.390$ to $+2.467)$ inside the prescribed scope of \pm 2.58 (Byrne, 2010) demonstrated a substantial impact of the latent variables on the model.

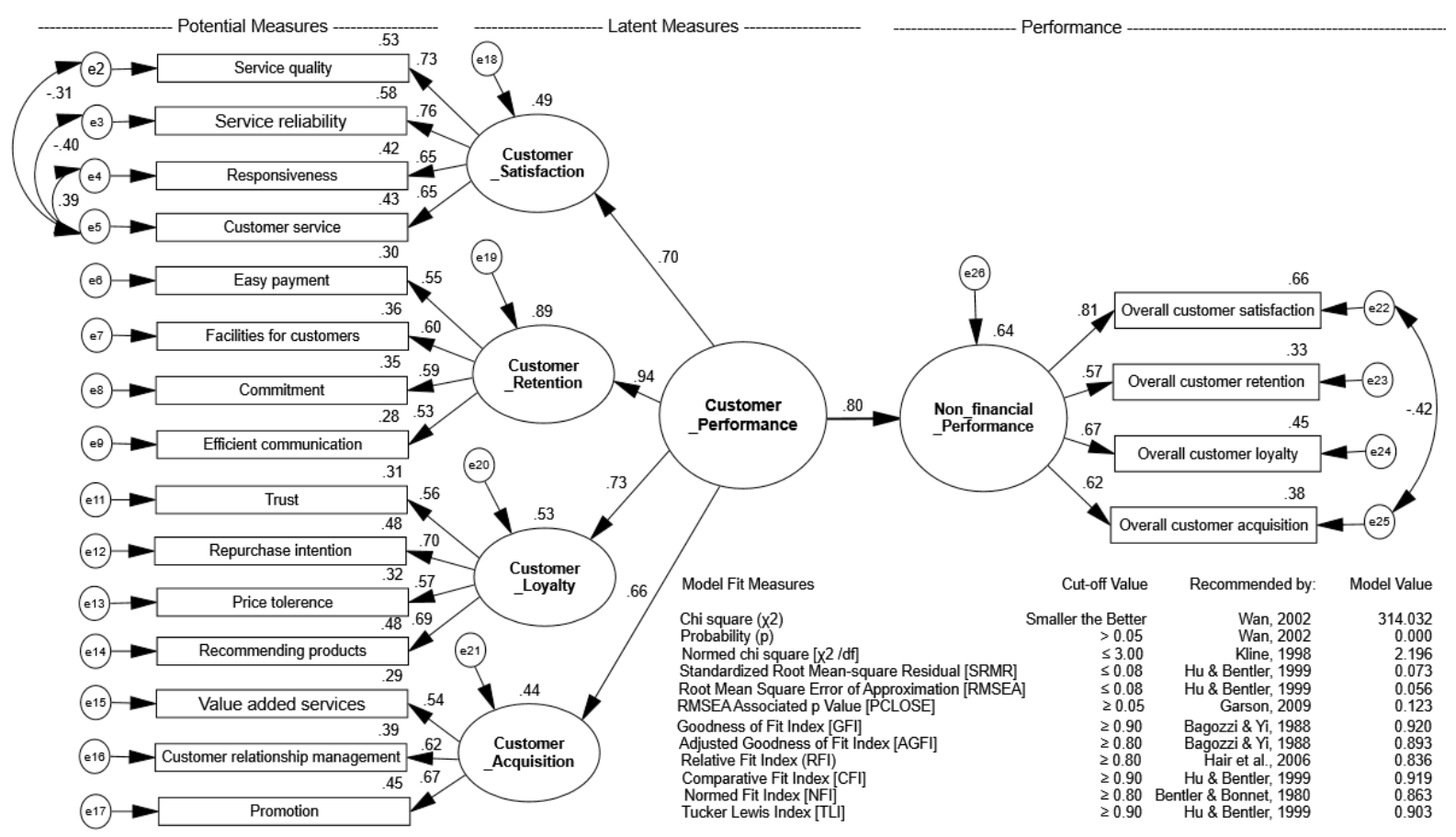

Figure 2. The study model 
Table 4. Parameter estimates

\begin{tabular}{|c|c|c|c|c|c|}
\hline Indicators & $\begin{array}{l}\text { Unstandardized } \\
\text { regression weights }\end{array}$ & $\begin{array}{l}\text { Standardized } \\
\text { regression } \\
\text { weights }\end{array}$ & $\begin{array}{l}\text { Standard } \\
\text { error }\end{array}$ & $\begin{array}{c}\text { Critical } \\
\text { ratio }\end{array}$ & $\begin{array}{c}p \text {-value } \\
\text { significant at } \\
0.01\end{array}$ \\
\hline $\mathrm{CP} \rightarrow \mathrm{NFOP}$ & 1.008 & 0.802 & 0.145 & 6.960 & $* * *$ \\
\hline $\mathrm{CS} \leftarrow \mathrm{CP}$ & 1.025 & 0.699 & 0.157 & 6.514 & $* * *$ \\
\hline$C R \leftarrow C P$ & 1.085 & 0.944 & 0.161 & 6.735 & $* * *$ \\
\hline $\mathrm{CL} \leftarrow \mathrm{CP}$ & 1.041 & 0.730 & 0.149 & 7.001 & $* * *$ \\
\hline $\mathrm{CA} \leftarrow \mathrm{CP}$ & 1.000 & 0.660 & & & \\
\hline Service quality $($ VAR_9) $\leftarrow$ CS & 1.110 & 0.731 & 0.139 & 7.972 & $* * *$ \\
\hline Service reliability $($ VAR_10) $\leftarrow$ CS & 1.063 & 0.760 & 0.134 & 7.914 & $* * *$ \\
\hline Responsiveness $($ VAR_11) $\leftarrow$ CS & 1.020 & 0.650 & 0.106 & 9.576 & $* * *$ \\
\hline Customer service $($ VAR_12) $\leftarrow$ CS & 1.000 & 0.652 & & & \\
\hline Easy payment $\left(V A R \_13\right) \leftarrow C R$ & 0.992 & 0.546 & 0.129 & 7.675 & $* * *$ \\
\hline Facilities for customers (VAR_14) $\leftarrow$ CR & 1.096 & 0.604 & 0.134 & 8.160 & $* * *$ \\
\hline Commitment $($ VAR_15) $\leftarrow C R$ & 1.022 & 0.593 & 0.127 & 8.078 & $* * *$ \\
\hline Efficient communication $\left(V A R \_16\right) \leftarrow C R$ & 1.000 & 0.529 & & & \\
\hline Trust $($ VAR_18) $\leftarrow \mathrm{CL}$ & 0.749 & 0.557 & 0.084 & 8.929 & $* * *$ \\
\hline Repurchase intention $\left(V_{A R} 19\right) \leftarrow C L$ & 1.036 & 0.695 & 0.099 & 10.504 & $* * *$ \\
\hline Price tolerance $($ VAR_20) $\leftarrow \mathrm{CL}$ & 0.851 & 0.569 & 0.094 & 9.083 & $* * *$ \\
\hline Recommending products $\left(V A R \_21\right) \leftarrow C L$ & 1.000 & 0.690 & & & \\
\hline Value added services $($ VAR_22) $\leftarrow$ CA & 0.742 & 0.542 & 0.095 & 7.628 & $* * *$ \\
\hline Customer relation management $($ VAR_23) $\leftarrow$ CA & 0.918 & 0.625 & 0.112 & 8.210 & $* * *$ \\
\hline Promotion $\left(V A R \_24\right) \leftarrow C A$ & 1.000 & 0.671 & & & \\
\hline Overall CS $($ VAR_25) $\leftarrow$ NFOP & 1.269 & 0.810 & 0.132 & 9.590 & $* * *$ \\
\hline Overall CR $($ VAR_26) $\leftarrow$ NFOP & 0.900 & 0.573 & 0.105 & 8.604 & $* * *$ \\
\hline Overall CL $($ VAR_27) $<$ NFOP & 1.051 & 0.674 & 0.111 & 9.488 & $* * *$ \\
\hline Overall CA $($ VAR_28) $\leftarrow$ NFOP & 1.000 & 0.620 & & & \\
\hline $\mathrm{e} 2 \leftrightarrow \mathrm{e} 5$ & -0.229 & -0.306 & 0.070 & -3.256 & $* * *$ \\
\hline e3 $\leftrightarrow$ e5 & -0.261 & -0.399 & 0.065 & -4.004 & $* * *$ \\
\hline $\mathrm{e} 4 \leftrightarrow \mathrm{e} 5$ & 0.331 & 0.387 & 0.088 & 3.785 & $* * *$ \\
\hline $\mathrm{e} 22 \leftrightarrow \mathrm{e} 25$ & -0.225 & -0.424 & 0.044 & -5.149 & $* * *$ \\
\hline
\end{tabular}

\section{DISCUSSION}

To recognize $\mathrm{CP}$ as an independent variable, the literature review identified 17 observed variables within four latent variables. Two of the observed variables: price fairness (VAR_8) and switching barriers (VAR_17), were not acknowledged though they were significant in the earlier studies like price fairness (Hermann et al., 2007; Khan \& Afsheen, 2012; Martin-Consuegra et al., 2007) and switching barriers (Danish et al., 2015; Fornell, 2007). Four observed variables were used to assess the latent variable NFOP as a dependent variable.

The latent variable CS was evaluated from four noticed factors: service quality $(\beta=0.731, p<$ $0.01)$; service reliability $(\beta=0.760, p<0.01)$; responsiveness $(\beta=0.650, p<0.01)$; and customer service $(\beta=0.652, p<0.01)$; they collectively influence $C P$, as suggested by the past studies (like Adebiyi et al., 2016; Hermann et al., 2007; Martin-Consuegra et al., 2007; Saha et al., 2016; etc.). The latent variable CR was assessed from four observed variables: easy payment $(\beta=0.546$, $p<0.01)$; facilities for customers $(\beta=0.604, p<$ $0.01)$; commitment $(\beta=0.593, p<0.01)$; and efficient communication $(\beta=0.529, p<0.01)$. In line with earlier research (like Fornell, 2007; Sanchez \& Iniesta, 2004; Sharma \& Patterson, 1999), the study indicated that the noticed factors directly influence CR and, therefore, CP.

The latent variable CL was also assessed from four observed non-financial measures: trust $(\beta=$ $0.557, p<0.01)$; repurchase intention $(\beta=0.695$, $p<0.01)$; price tolerance $(\beta=0.569, p<0.01)$; and recommending products $(\beta=0.690, p<0.01)$. Such measures were also significant in the earlier studies like Herrmann et al. (2004), Lee et al. (2001), Lin and Wang (2005), Mayer et al. (1995), Oliver (1997), Zeithaml et al. (1996), and so forth. 
The examination findings uncovered that the factors directly impact CL and, indirectly, CP. Such outcomes were likewise steady with Balaji's (2009) conclusions that delighted customers tolerate price and stay loyal to their present service provider. In addition, delighted customers develop trust and commitment to the mobile service provider, enhancing the company's image and reputation. Evidence showed that CL towards service providers focuses on creating long-term associations with an organization. The latent variable CA was evaluated from three noticed factors: value-added services $(\beta=0.542, p<0.01)$; customer relationship management $(\beta=0.625, p<0.01)$; and promotion $(\beta=0.671, p<0.01)$. Like earlier studies (Khan, 2012; Rahman et al., 2010, and others), the study revealed that the variables directly influence $\mathrm{CA}$ and indirectly CP.
The effect of each latent measure had been defined in hypothesis testing. The result of testing $\mathrm{H1}$, i.e., CP's effect on NFOP $(\beta=0.802, \mathrm{CR}=6.960, p<$ 0.01 ), showed a positive and significant relationship; hence, $H 1$ is accepted. The analysis indicated that CR was a better predictor of $\mathrm{CP}(\beta=0.944, p$ $<0.01)$ and followed by CL $(\beta=0.730, p<0.01)$; CS $(\beta=0.699, p<0.01)$; and CA $(\beta=0.660, p<$ 0.01 ). All the latent variables positively and significantly contributed to the $\mathrm{CP}$ having an excellent level of AVE $=0.638$ and $\mathrm{CoR}=0.894$ in the NCTI. Hence, the sub-hypotheses H1a, H1b, H1c, and $H 1 d$ were accepted. Obtaining new customers is more expensive than retaining existing customers, so this has a financial impact on the company and its overall performance. Evidence also proved that retention of the existing customers has the greatest importance, followed by CL and CS in the CP.

\section{CONCLUSION}

Multiple dimensions of non-financial measures in OP have been acknowledged since the 1990s. Identification of non-financial measures as leading indicators and their integration was the revolutionary changes in the performance management and measurement system during the last three decades. The key achievement of this time has been the inclusion of this area of stakeholder theory. Suitable initiatives allow organizations, along with their stakeholders, to accurately evaluate and enhance the exchange of values. Hence, the idea of subjective knowledge had been used to gauge organizational efficiency by considering one of the stakeholders (customers) as the respondent for the analysis. The study aimed to illustrate the need to adjust the context in which performance assessments were used and to overcome conventional performance practices in selected performance management approaches. The characteristics of the cellular telecommunications network, which mainly affect $\mathrm{CP}$ when utilizing the GSM services in Nepal, were identified, and their effects on NFOP were determined empirically by the study.

\section{Limitations and avenues for future scope}

Although the study provides unique insights into organizational performance measurement system's underlying mechanisms, it was subjected to some limitations. The study of the non-financial aspect of $\mathrm{CP}$ spans diverse fields, and methodological approaches vary significantly. Besides the logged variables in the study, other measures of CP like market share, total area coverage, teledensity, and an average number of customers per employee also affect the $\mathrm{CP}$ that was not considered. It was difficult to study the examination thoroughly. So, it was referred to as delegate instead of endeavoring to be thorough. The dependability of the examination's outcomes might be contingent upon the number of respondents and might have been improved further by a more extensive example. A more prominent example size for the insightful survey would have amplified the outcomes' legitimacy and consensus.

The study sample was taken from the GSM customers of the NCTI, and the conclusions can be derived from different ventures or territories to get a sensible opinion and weigh if the outcomes are material in an international arena. The data assortment for the study was done at one point in time; for future research, this will be a substantially preferred position for analyzing organizations in various fields to 
notice the impacts of CP to NFOP on OP. The chosen set of latent constructs in the study was not exhaustive. Future research could examine other variables that may also play an essential role in the $\mathrm{CP}$ to NFOP to OP link. There are other areas for future research, such as examining the boundaries of the relationships between $\mathrm{CP}$, NFOP, and OP, observing potential demographic moderators of the relationship between CP and NFOP, etc.

\section{Implications}

The study offers an insight into consumer preferences and expectations for the GSM service providers in Nepal. The service provider should intend to upgrade its quality of service constantly as it attracts and makes it possible for customers to continue for a long time with such cellular telecommunication services. The operator companies must tailor their product/service to provide efficient service to improve customers' satisfaction, retention, and loyalty. The study's findings may set up the intervening role of NFOP in the relationship between CP and OP.

Measuring performance is much more than tables of numbers and scorecards. Thus, the study is expected to contribute to the performance measurement system by providing validated non-financial measures and an increased understanding of organizational outcomes in the Nepalese scenario. The findings incorporate and stretch out literature to advocate that organizations can acquire a competitive advantage by exposing apprehension for their customers (as the key driver of OP) and not simply organizing attractive and powerful product/service advertising. The study complements the literature by offering insight into the advantages of non-financial CP measures in the Nepalese scenario. It proposes a subjective perspective on performance measurement through a new lens and provides theoretical and managerial implications in the NCTI's performance measurement system.

\section{AUTHOR CONTRIBUTIONS}

Conceptualization: Rewan Kumar Dahal.

Data curation: Rewan Kumar Dahal.

Formal analysis: Rewan Kumar Dahal.

Funding acquisition: Rewan Kumar Dahal.

Investigation: Rewan Kumar Dahal.

Methodology: Rewan Kumar Dahal.

Project administration: Rewan Kumar Dahal.

Resources: Rewan Kumar Dahal.

Software: Rewan Kumar Dahal.

Supervision: Rewan Kumar Dahal.

Validation: Rewan Kumar Dahal.

Visualization: Rewan Kumar Dahal.

Writing - original draft: Rewan Kumar Dahal.

Writing - review \& editing: Rewan Kumar Dahal.

\section{REFERENCES}

1. Adebiyi, S. O., Shitta, H. A. \& Olonade, O. P. (2016).

Determinants of customer preference and satisfaction with Nigerian Mobile Telecommunication services. BVIMSR's Journal of Management, 8(1), 1-12.
2. Ahmad, K., \& Zabri, S. M. (2016a). The application of non-financial performance measurement in Malaysian Manufacturing Firms. Procedia Economics and Finance, 35, 476-484. https://doi.org/10.1016/ S2212-5671(16)00059-9
3. Amir, A., \& Lev. B. (1996). Value relevance of non-financial information: The wireless communications industry. Journal of Accounting and Economics, 22(13), 3-30. https://doi.org/10.1016/ S0165-4101(96)00430-2 
4. Atkinson, A. A., Kaplan, R. S., Matsumura, E. M., Young, S. M., \& Kumar, G. A. (2014) Management Accounting Information for Decision Making and Strategy Execution (6th Ed.) New Delhi: Pearson Education, Inc.

5. Bagozzi, R., \& Yi, Y. (1988). On the evaluation of structural equation models. Journal of the Academy of Marketing Science, 16(1), 74-94. https://link.springer.com/article/10.1007/BF02723327

6. Balaji, M. S. (2009). Customer satisfaction with Indian mobile services. IUP Journal of Management Research, 8(10), 5262. https://papers.ssrn.com/sol3/ papers.cfm?abstract_id=1483604

7. Bentler, P. M., \& Bonnet, D. G. (1980). Significance tests and goodness of fit in the analysis of covariance structures. Psychological Bulletin, 88, 588-606. Retrieved from https://psycnet.apa.org/ doi/10.1037/0033-2909.88.3.588

8. Bosse, D. A., Phillips, R. A., \& Harrison, J. S. (2008). Stakeholders, reciprocity, and firm performance. Strategic Management Journal, 30, 447-456. http://dx.doi.org/10.1002/ smj.743

9. Bowerman, B. L., O'Connell, R. T., \& Orris, J. B. (2004). Essential business statistics (3rd ed.). New York: McGraw-Hill.

10. Briggs, J., Claiboborne, M. C., \& Cole, E. (2006). Total optimal performance scores: a practical guide for integrating financial and non-financial measures in performance evaluation. Management Accounting Quarterly, 8(1), 11-23. https://gent.uab.cat/ diego_prior/sites/gent.uab.cat. diego_prior/files/Reading_3_3_ Briggs_2006.pdf

11. Byrne, B. M. (2010). Structural equation modeling with $A M O S$ basic concept, application, and programming (2 ed.). New York: Taylor \& Francis Group, LLC.

12. Clark, L. A., \& Watson, D. (1995). Constructing validity: Basic issues in objective scale development. Psychological Assessment, 7(3) 309-319. https://psycnet.apa.org/ doi/10.1037/1040-3590.7.3.309
13. Cho, Y.J., \& Lee, J.W. (2012). Performance management and trust in supervisors. Review of Public Personnel Administration, 32(3), 236-259. https://doi. org/10.1177/0734371X11421496

14. Colgate, M., \& Danaher, P. J. (2000). Implementing a customer relationship strategy: The asymmetric impact of poor versus excellent execution. Journal of the Academy of Marketing Science, 28(3), 375-387. https://link.springer.com/article/10.1177/0092070300283006

15. Danish, R. Q., Ahmad, F., Ateeq, A., Ali, H. Y., \& Humayon, A. A. (2015) Factor affecting customer retention in the telecom sector of Pakistan. American Journal of Marketing Research, 1(2), 28-36.

16. Fornell, C. (2007). A national customer satisfaction barometer: The Swedish experience. Journal of Marketing, 56(1), 6-21. https://doi. org/10.2307/1252129

17. Fornell, C., \& Larcker, D. F. (1981). Evaluating structural equation models with unobservable variables and measurement error. Journal of Marketing Research, 18(1), 39-50. https://doi.org/10.1177\% 2F002224378101800104

18. Franco-Santos, M., Kennerley, M, Micheli, P., Martinez, V., Mason, S., Marr, B., Gray, D., \& Neely, A. (2004). Towards a definition of a business performance measurement system. The Six-international conference on performance measurement (395405). University of Cambridge, UK.

19. Garson, G. D. (2009). Structural equation modeling. Retrieved June 2018, from http://faculty.chass.ncsu. edu/garson/PA765/structur.htm

20. George, D., \& Mallery, M. (2010). SPSS for windows step by step: A simple guide and reference, 17.0 update (10th ed.) Boston: Pearson.

21. Hair, J. F., Black, W. C., Babin, B. J., Anderson R. E., \& Tatham R. L. (2006). Multivariate data analysis. New Jersey: Prentice-Hall, Pearson Education, Inc.

22. Halstead, D., Hartman, D., \& Schmidt, S.L. (1994). Multisource effects on the satisfaction formation process. Journal of the Academy of Marketing Science, 22, 114-29. https:// link.springer.com/article/10.1177/0092070394222002

23. Henri, J. F. (2006). Organizational culture and performance measurement systems. Accounting, Organizations, and Society, 31(1), 77-103. https://doi.org/10.1016/j. aos.2004.10.003

24. Herrmann, A., Huber, F., Sivakumar, K., \& Wricke, M. (2004). An empirical analysis of the determinants of price tolerance. Psychology and Marketing, 21(7), 533-551. http://dx.doi.org/10.1002/ mar.20018

25. Herrmann, A., Xia, L., Monroe, K. B., \& Huber, F. (2007). The influence of price fairness on consumer satisfaction: An empirical test in the context of automobile purchases. Journal of Product \& Brand Management, 16(1), 49-58. https://doi. org/10.1108/10610420710731151

26. Hu, L., \& Bentler, P. (1999). Cut-off criteria for fit indices in covariance structure analysis: conventional criteria versus new alternatives. Structural Equation Modeling A Multidisciplinary Journal, 6(1), 1-55. https://doi. org/10.1080/10705519909540118

27. Ittner, C. D., Larcker, D. F., \& Rajan, M. V. (1997). The choice of performance measures in annual bonus contracts. The Accounting Review, 72(2), 231-255.

28. Ittner, C. D., \& Larcker, D. F. (1998b). Are non-financial measures leading indicators of financial performance? An analysis of customer satisfaction. Journal of Accounting Research, 36, 1-35. https://doi.org/10.2307/2491304

29. Ittner, C. D., Larcker, D. F., \& Taylor, D. (2009). Commentary the stock market's pricing of customer satisfaction. Marketing Science, 28(5), 826-835. https://doi. org/10.2307/2491304

30. Jacobson, R., \& Mizik, N. (2009). The financial markets and customer satisfaction: Reexamining possible financial market mispricing of customer 
satisfaction. Marketing Science, 28(5), 810-819. http://dx.doi. org/10.1287/mksc.1090.0495

31. Joshi, S., Khurana, P., \& Khurana, S. (2010). Service quality in the telecommunication sector - A study of telecom services providers of Chandigarh, Panchkula, and Mohali. Sri Krishna International Research and Educational Consortium, 1(1), 90-99. http://docshare02.docshare. tips/files/12113/121131335.pdf

32. Kaplan, R. S., \& Norton, D. P. (1996). The balanced scorecard: Translating strategy into action. Boston: Harvard Business School Press.

33. Karatepe, O. M. (2012) Perceived organizational support, career satisfaction, and performance outcomes: A study of hotel employees in Cameroon. International Journal of Contemporary Hospitality Management, 24(5), 735- 752. https://doi. org/10.1108/09596111211237273

34. Khan, M. A. (2010). An empirical assessment of the service quality of cellular mobile telephone operators in Pakistan. Asian Social Science, 6(10), 164-177. https://doi. org/10.5539/ass.v6n10p164

35. Khan, S. (2012). Contribution of brand awareness and brand characteristics towards customer loyalty - A study of the milk industry of Peshawar Pakistan. Journal of Asian Business Strategy, 2(8), 170-176. http://www.aessweb. com/pdf-files/JABS-2(1)42-170176.pdf

36. Khan, S., \& Afsheen, S. (2012). Determinants of customer satisfaction in the telecom industry - A study of telecom industry Peshawar KPK Pakistan. Journal of Basic and Applied Scientific Research, 2(12), 12833-12840. https://www. textroad.com/pdf/JBASR/J.\%20Basic.\%20Appl.\%20Sci.\%20Res.,\%20 2(12)12833-12840,\%202012.pdf

37. Kim, M., Park, M., \& Jeong, D. (2004). The effects of customer satisfaction and switching barrier on customer loyalty in Korean mobile telecommunication services. Telecommunications
Policy, 28, 145-159. https://doi. org/10.1016/j.telpol.2003.12.003

38. Kline, R. B. (1998). Methodology in the social sciences: Principles and practice of structural equation modeling. New York: Guilford Press.

39. Kolstad, J. T. (2013). Information and quality when motivation is intrinsic: Evidence from surgeon report cards. The American Economic Review, 103(7), 2875 2910. https://www.aeaweb.org/ articles? $\mathrm{id}=10.1257 /$ aer $\cdot 103.7 .2875$

40. Krejcie, R., \& Morgan, D. (1970). Determining sample size for research activities. Educational \& Psychological Measurement, 30, 607-610. https://doi.org/10.1177\% 2F001316447003000308

41. Lai, F., Hutchinson, J., Li, D., \& Bai, C. (2007). An empirical assessment and application of SERVQUAL in mainland China's mobile communications industry. International Journal of Quality and Reliability Management, 24(3), 244-262. https://doi. org/10.1108/02656710710730852

42. Lee, J., Lee, J., \& Feick, L. (2001). The impact of switching costs on customer satisfaction - loyalty link: Mobile phone service in France. Journal of Services Marketing, 15, 35-48. https://doi. org/10.1108/08876040110381463

43. Lin, H.-H., \& Wang, Y.-S. (2006). An examination of the determinants of customer loyalty in mobile commerce contexts. Information \& Management, 43, 271-282. https://doi.org/10.1016/j. im.2005.08.001

44. Lebas, M. J. (1995). Performance measurement and performance management. International Journal of Production Economics, 41, 23-35.

45. Martin-Consuegra, D., Molina, A., \& Esteban, A. (2007). An integrated model of price, satisfaction, and loyalty: An empirical analysis in the service sector. Journal of Product \& Brand Management, 16(7), 459-468. https://doi. org/10.1108/10610420710834913

46. Mayer, R. C., Davis, J. H., \& Schoorman, F. D. (1995). An integrative model of organizational trust. Academy of Management Review, 20(3), 709-734. https://doi. org $/ 10.2307 / 258792$

47. McKinley, R. K., Manku-Scott, T., Hastings, A. M., French, D.P., \& Baker, R. (1997). Reliability and validity of a new measure of patient satisfaction with out of hours' primary medical care in the United Kingdom: development of a patient questionnaire. British Medical Journal, 314(7075), 193-198. https:// doi.org/10.1136/bmj.314.7075.193

48. Meyers, L. S., Gamst, G., \& Guarino, A. J. (2006). Applied multivariate research: Design and interpretation. Sage Publications, Inc.

49. Michaela, S., \& Marketa, S. (2012). Review and comparison of performance measurement systems. Journal of Organizational Management Studies. http://dx.doi. org/10.5171/2012.114900

50. Moullin, M. (2003). Defining performance measurement. Perspectives on Performance, 2(2), 3.

51. Nunnally, J. C. (1993). Psychometric theory (3rd ed.). New York: McGraw-Hill.

52. Oliver, R. L. (1997). Satisfaction: a behavioral perspective on the consumer. New York: McGrawHill.

53. Omotayo, O., \& Jachim, A. (2008). Customer in the retention of mobile users in Nigeria. African Journal of Business Management, 2(2), 26-31. https://academicjournals.org/ article/article1380537583_Omotayo\%20and\%20Joachim.pdf

54. Omran, M., Khallaf, A., Gleason, K., \& Tahat, Y. (2019). Nonfinancial performance measures disclosure, quality strategy, and organizational financial performance: A mediating model. Total Quality Management \& Business Excellence, 1-25. https:// doi.org/10.1080/14783363.2019.1 625708

55. Paulrajan, R., \& Rajkumr, H. (2011). Service quality and customer preference for cellular mobile service providers. Journal of Technology Management and Innovation, 6(1), 38-45. http:// dx.doi.org/10.4067/S071827242011000100004 
56. Podsakoff, P. M., MacKenzie, C. B., Lee, J-Y., \& Podsakoff, N. P. (2003). Common method biases in behavioral research: A critical review of the literature and recommended remedies. Journal of Applied Psychology, 88(5), 879903. https://doi.org/10.1037/00219010.88.5.879

57. Rahman, S., Haque, A., \& Ahmad, M. (2011). Choice criteria for mobile telecom operator: Empirical investigation among Malaysian customers. International Management Review, 7(1), 50-57. http://irep.iium.edu. $\mathrm{my} / 3856 /$

58. Reichheld, F. F. (1996). The loyalty effect: The hidden force behind growth, profits, and lasting value. MA, Boston: Harvard Business School Press.

59. Richard, P. J., Devinney, T. M., Yip, G. S., \& Johnson,
G. (2009). Measuring organizational performance: Towards methodological best practice. Journal of Management, 35(3), 718-804. http://dx.doi. org/10.1177/0149206308330560

60. Saha, N. K., Islam, M. R., \& Hoque, A. U. (2016). Factors affecting customers' satisfaction of mobile phone subscribers: an empirical study on the mobile telecommunication industry in Bangladesh. International Journal of Business and Management, 11(6), 252-261. https://doi. org/10.5539/ijbm.v11n6p252

61. Sanchez, M. N., \& Iniesta, M. A. (2004). The structure of commitment in consumer-retailer relationships: conceptualization and measurement

International Journal of Service Industry Management 15(3), 230-249. https://doi. org/10.1108/09564230410540917
62. Sharma, N., \& Patterson, P. G. (1999). A model of relationship commitment among professional services. Journal of Services Marketing, 13(2), 151-170.

63. Wan, T.T.H. (2002). Evidencedbased health care management: Multivariate modeling approaches Norwell, MA: Kluwer Academic Publishers.

64. Wang, Y., \& Lo, Hing-Po. (2002). Service quality, customer satisfaction, and behavior intentions: Evidence from China's telecommunication industry. Managing Service Quality, 4(6), 50-60. https://doi. org/10.1108/14636690210453406

65. Zeithaml, V. A., Berry, L. L., \& Parasuraman, A. (1996). The behavioral consequences of service quality. Journal of Marketing, 60(2), 31-46. https://doi. org/10.2307/1251929 